\title{
REVOLUTION OR DIVERSITY? AESTHETIC AND POLITICAL \\ MANIFESTATIONS OF CLASS IN THREE SWEDISH RADICAL PICTUREBOOKS FROM THE 2000S AND $2010 S$
}

\section{Kristina Hermansson}

\section{ABSTRACT}

This article explores manifestations of class from a combined aesthetical and political point of view, focusing on a selection of Swedish children's picture books from 2009 to 2018, in which class differences are made prominent. In this sense, they can be regarded as radical. This study examines how political aspects are intertwined with literary, visual, and multimodal means. The main purpose is to examine how the political and aesthetical merge in the manifestations of class. The publishing of radical picture books during the 2000s and 2010 s coincided with a rise of norm-critical discourse, including a strong emphasis on diversity rather than on social transformation. The books, I argue, do not depict radical change on a collective level, but uses various aesthetic means in their manifestations of class and inequality. Theoretically, the analysis mainly draws on Pierre Bourdieu's theory of capital (1984), and Beverley Skeggs's (1997) reasoning on class by adding the concept of respectability, as well as picturebook theory, and scholarly writing on radical picturebooks.

\section{KEYWORDS}

Children's Literature, Picturebook, Iconotext, Class, Capital, Respectability, Diversity 


\section{INTRODUCTION}

Some children's picturebooks that approach issues of class and class differences offer primarily a broader scope of representation, while others also encompass or promote social transformation. Manifestations of class come in various literary and visual modes of telling, with different aesthetical and political functions. During the 2000s and 2010s, diversity regarding social settings, characters, experiences, and narrative perspectives increased. According to the Swedish Institute for Children's Books, the publishing of socially engaged children's picturebooks became especially notable in 2018. The characteristic feature of these picturebooks was their "paying attention to injustice, making social and economic differences visible and engaging children in acts of protest". ${ }^{1}$

Contemporary Swedish picturebooks regularly approach issues such as migration, poverty and homelessness, though in a somewhat different way compared to the often more explicitly left-wing radical children's literature of the 1960s and 1970s. ${ }^{2}$ The emphasis on diversity is in line with an increasingly influential norm-critical discourse in Sweden during the 2000s when a handful of self-labelled norm-critical publishing houses opened with the purpose of publishing non-stereotyped and more inclusive children's literature. This also meant a slightly increased variation in representations of class, at least since about half a decade. ${ }^{3}$ The renewed social engagement in children's picturebooks has engendered little scholarly attention compared to the work devoted to radical children's literature of the $1960 \mathrm{~s}$ and 1970s. This article intends to contribute to the earlier research on politically radical picture books and to explore the political functions of aesthetic expressions in my primary material consisting of Swedish picturebooks from a ten year period. The main purpose is to examine how class and class differences are made manifest by various literary modes, to discern potential patterns in the use of aesthetic means and in their political function. The study focuses on a small selection of picturebooks published in 2009-2018: Siv Sleeps Astray (Siv sover vilse, 2009)4 by Pija Lindenbaum, The Week Before Child Benefit Payment (Veckan före barnbidraget, 2016) ${ }^{5}$ by Ellen Ekman and Elin Johansson, and At Harald Henriksson's Home (Hemma hos Harald Henriksson, 2018) ${ }^{6}$ by Uje Brandelius and Clara Dackenberg.

These titles are selected due to their thematization of class differences and their different uses of multimodal aesthetic and political means of telling. All these books depict a class 
subordination from the child protagonist's perspective, displaying in various ways the experiences of discrimination, power, and financial scarcity. In Siv' Sleeps Astray, the scholarly comments on class concentrate on realistic depictions of space, interior, and food. The other two titles have received attention primarily due to their supposed realistic manifestations of class in terms of poverty but also of space and food. By bringing the three titles together, in this analysis I aim to explore political functions of the radical picturebook in Sweden of the 2000s and 2010s. As I will try to show, the aesthetic manifestations of class vary, yet, there is political potential in their making visible of class differences and (some of) their consequences.

This study aims to examine how aspects like fantasy, humour, intertextual relations, and different literary and pictorial strategies interplay, and their radical political function. Different literary modes of telling are intertwined with political aspects. I argue that there is an emphasis on diversity and inclusiveness rather than on social transformation in the radical picturebook of the 2000s and the 2010s. If a change is promoted it is primarily to do with the protagonist's attitudes than with the circumstances. The primary questions dealt with are the following: How is class manifested verbally and visually? How can the political functions of the various aesthetic modes of expression be comprehended? The study aims to contribute to current research by scrutinizing how various realistic and non-realistic narrative modes contribute to the manifestation of class and class differences, and their political functions.

\section{CHILDREN'S PICTUREBOOKS ON CLASS. SURVEY OF THE FIELD}

Before we get into the contemporary manifestations of class, I will provide a brief background of the field of children's literature from the politically radical period from around 1969 until now.

During the late 1960s and early 1970s, radical children's literature had an upswing in many Western countries, including Sweden. This meant new standards regarding form and content of children's literature and an emphasis on social realism (Mickenberg, Reynolds, Weinrech). In Sweden, radical publishers like Ordfront and Gidlunds saw the light of day. There are numerous studies of the often more explicit multimodal radical children's literature. Most scholarly writing focuses on the socalled Verdandi picturebooks, a series by a radical student association co-operating with the big publishing house Rabén \& Sjögren. ${ }^{7}$ Like many other children's books at the time, the series 
aimed to inform children of social injustices using a socialist framework. Some books were documentaries about living conditions in South America or Africa, like Josefine, 5, Zimbabwe, Afrika ${ }^{8}$, while some were absurd and humoristic fiction like The Nailing Gang (Spikarligan), ${ }^{9}$ depicting a revolution led by three boys obsessed by woodcraft, or Toff Went to the Toilet (Sprätten satt på toaletten), ${ }^{10}$ displaying environmental issues in a capitalistic context.

There are several studies of this period in Swedish radical children's literature. In his studies of children's literature from around 1968, Olle Widhe claims that aesthetic radicalness is often an aspect of political radicalness that tends to be overshadowed by the focus on social realist narrative modes. ${ }^{11}$ Drawing on this notion, I intend to explore how aesthetic and political aspects merge in the depiction of class in more recent picturebooks, published in a less progressive historical period.

As Widhe states, when summarizing the tendency of social engagement in children's literature published in 2018, there is no clear enemy, in contrast to some radical children's books from the 1970s. Rather, the focus is on children's experiences, meaning that the causes of supposed inequalities remain more or less hidden for the reader. ${ }^{12}$ This notion is confirmed by Lydia Wistinsen's study of a selection of contemporary Swedish children's picturebooks from the 2010s, including The Week Before Child Benefit Payment and At Harald Henrikssons's Home. The analysis highlights verbal and visual depictions of poverty in relation to discourses of poverty and children's rights. Wistinsen claims that the representations of poverty manifest both traditional and radical discourses. In contrast to the often more politically explicit radical children's literature of the 1960s and 1970s, contemporary socially engaged picturebooks are described as more subtle, offering ambiguity and reflection. ${ }^{13}$

In relation to two other realistic literary works on poverty in the contemporary welfare state, Anna Nordenstam focuses the child's perspective on the lack of money depicted in The Week Before Child Benefit Payment: "This is Swedish every day realism”, Nordenstam states. ${ }^{\mathbf{1 4}}$ Without doubt, it is. Nevertheless, there are other features of verbal and visual presentation worth paying attention to. In my reading, I intend to illustrate the various expansions and aesthetic variations of the realistic approach to class and examine how they integrate with political aspects.

In comparison to my first mentioned two examples, there exists a more extensive research on the more well-established 
and widely translated author and illustrator Pija Lindenbaum, who had her debut in 1990 with the picturebook Else-Marie and Her Seven Little Daddies ${ }^{15}$ (Else-Marie och småpapporna). ${ }^{16}$ In several articles, literary scholar Mia Österlund penetrates the construction of gender in Lindenbaum's picturebooks. One of her articles explores the transformation of girlhood, where the construction of gender is described as "gurlesque," pointing at a specific feminine-grotesque doing of girlhood. ${ }^{17}$ A few other studies deal with Siv's First Sleepover. Österlund also examines gender aspects of Lindenbaum's Bridget series (Orig.: Gittan). ${ }^{18}$ Österlund uses the term 'gurlesque,' anchored in queer theory, to analyse the conflation of conventional girlish attributes, for instance the colour pink, with elements of danger or aggression. While the study mainly concentrates on other works, it also mentions Siv Sleeps Astray. Österlund discusses the exaggerated pink room featured in the book, in relation to pink poetics and the contestation of colour with practices of subversion. ${ }^{19}$ In an article in Nordic Women's literature, Östlund briefly describes the book as dealing with friendship from a class perspective. ${ }^{20}$

Åsa Warnqvist sheds lights on Lindenbaum's ambiguous relations to social norms by analysing three picturebooks, including Siv Sleeps Astray. The short passage on this specific picturebook focuses on the thematic 'belonging' in relation to class differences. Warnqvist notes the protagonist's uses of fantasy when she experiences injustices at her friend's more privileged home. ${ }^{21}$

My analysis aims to further explore political and aesthetic aspects of the manifestations of class by focusing on the intertwining of literary and visual narrative strategies and their political potential. In short, this study aims to contribute to earlier scholarly writings by examining the manifestations of class, not only by concentrating on realistic features of the verbal and visual text but also by paying attention to the functions of various literary modes of telling.

\section{THEORETICAL STARTING POINTS}

Kimberly Reynholds claims that there is a certain radical potential in children's literature per se: "[C]hildren's literature contributes to the social and aesthetic transformation of culture by, for instance, encouraging readers to approach ideas, issues, and objects from new perspectives and so prepare the way for change.”22 It is notable that Reynolds refers to both social and aesthetic transformation, not as synonymous with, but as a 
different aspect of the supposed transformative potential that may be more or less pronounced.

Transformation is also a key concept in Clémentine Beauvais's reasoning on, what she calls, politically committed children's literature, which is associated with social transformations on various levels. ${ }^{23}$ According to Julia Mickenberg and Philip Nel, radical children's books push readers to identify with the poor or to recognize their own privilege. Further, they claim that the supposed radicality may concern matters of equality but also flawed assumptions of children and childhood. 24

In my analysis of picturebook manifestations of class, I will draw on these conceptualizations of radical literature, primarily Reynold and Beauvais. To analyse the specific verbal, visual, and icono-textual, 25 aspects of the literary works, I will also utilize sociological theory, especially Pierre Bourdieu's concept of 'symbolic capital'. In his conception of class, Bourdieu identifies three types of capital: social, economic, and cultural. Social capital means the amount of access to relevant networks. Economical capital is about material assets, such as income or savings. Cultural capital refers both to relevant education and knowledge about social and cultural codes needed in a specific environment. It is important to stress that the value of certain capital may vary in different contexts. Further, the access to capital relates to sex/gender, class, nation, cultural background, age and function. ${ }^{26}$

In addition, I will utilize Beverly Skeggs's feministic class theory, focusing the concept of respectability. For the less privileged, respectability might be something to urgently pursue. Respectability is associated with moral authority, social value, and legitimacy: "a property of middle-class individuals defined against the masses.”27 In her anthropological study, Skeggs show how being a working-class woman may imply disassociation rather than association; an attempt not to be recognized as part of the working class in order to achieve respectability. ${ }^{28}$

\section{MAKING ENDS MEET}

The Week Before Child Benefit Payment is Elin Johansson's literary debut, followed by Staying at Home All Summer (Hemma hela sommaren, 2018). ${ }^{29}$ Both are illustrated by Ellen Ekman, author and illustrator of several comics and comic strips. The first book depicts a week and the other a summer in the life of a child and mother by presenting significant moments where their economic situation becomes pronounced. This analysis 


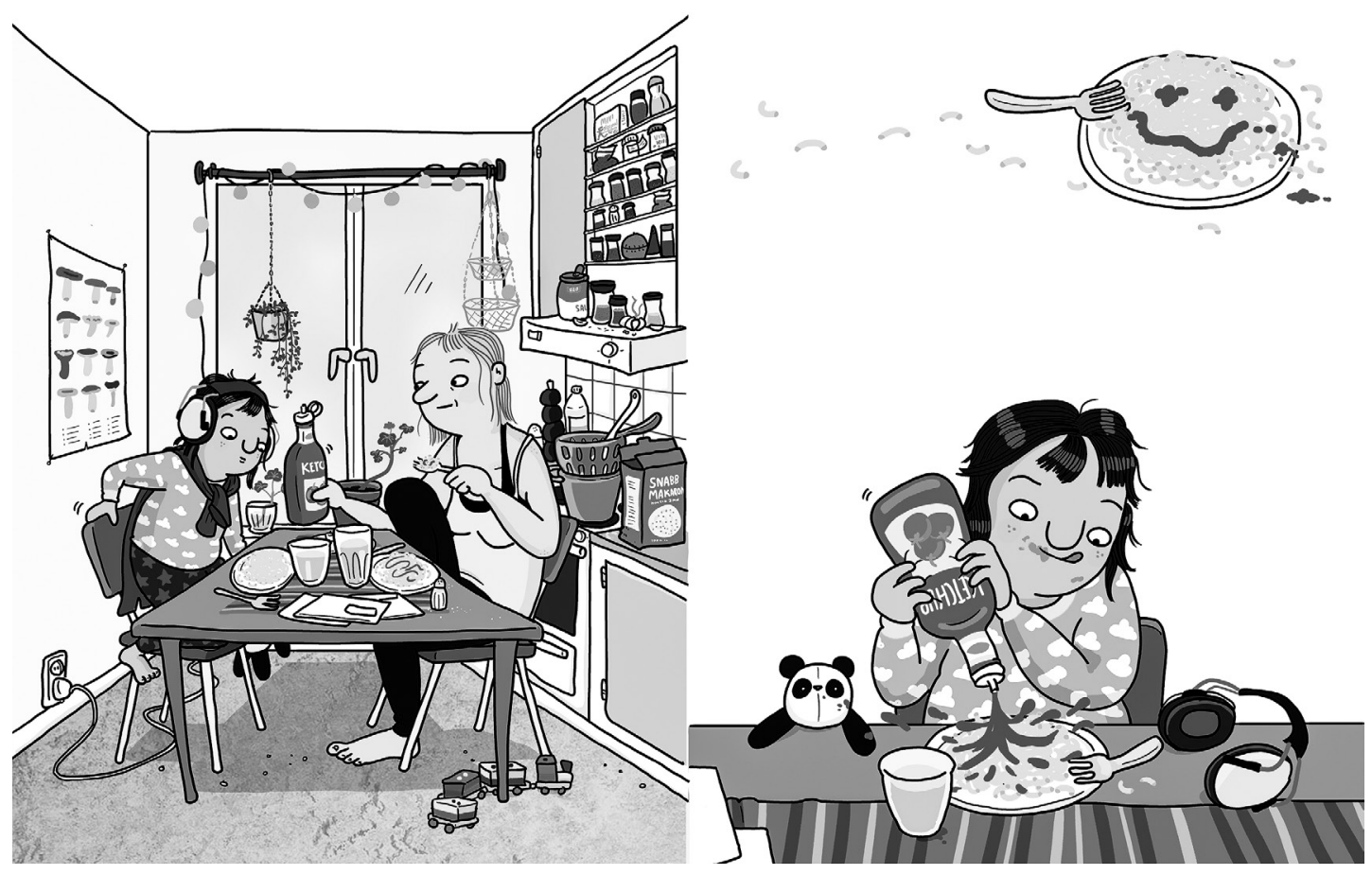

Fig. 1

The sparse dialogue expanded by the detailed pictures in The Week Before Child Benefit Payment (2016). 
concentrates on Johansson's debut, but will relate to the second title when relevant.

The protagonist/narrator appears to be around five to seven years old, presented visually with rounded shapes and with medium long brown hair. As in many comics, the characters are depicted with four fingers on each hand, though it in this case this feature deviates from the social realistic approach. The protagonist/narrator is not clearly gendered, verbally or visually. In the 2000s and forward, several non-gendered children appeared in Swedish picturebooks, for instance in Siri Reuterstrand's books about a child called Ellis and the much talked about Kivi and the Monsterdog (Kivi och Monsterhund, 2012) by Jesper Lundqvist and Bettina Johansson who introduced the gender-neutral pronoun (in Swedish, 'hen') in children's literature. According to Österlund, there are two dominating strategies towards construction of gender in contemporary picturebooks: to blur or to make visible. ${ }^{30}$ The visual portrayal of the protagonist in The Week Before Child Benefit Payment blurs contested female and masculine features: the hair is neither long nor short, the clothing contains various colours and patterns. The illustrations contain both female, masculine, and more or less gender-neutral toys, for instance My Little Ponies, Lego, dolls and cars. However, the adult characters are visually and/or verbally gendered though not stereotyped or idealized. For instance, the mother's legs are depicted with hair on, and small whales of fat are part of her visual appearance, indicating a norm-critical or body positivity approach. ${ }^{31}$

The book's informative title refers to a benefit that is similar for all parents in Sweden; the amount of money depends on the number of children but not the size of income. It is not stated how the mother gets her income, whether she is unemployed or employed, if she is a student or on sick leave, or perhaps dependent on social benefits from the state. This omission of information regarding the mother is congenial with the child's perspective of the story. ${ }^{32}$

The iconotext is most often complementary: pictures fill verbal gaps, and vice versa. ${ }^{33}$ The writing is quite straightforward, while the visual interplay adds social context and symbols, and often expands the everyday realism in the sparse text. The pictures also sometimes put to the fore a playfulness, as a means of handling the economic situation. There are also more ambivalent dimensions of play, as the earmuffs on the picture below.(Fig. 1)

In both titles by Johansson and Ekman, other children talk about their plans to do things like going to the cinema or on some 
kind of expensive holiday trip. The narrator sometimes claims to have similar plans. In Staying Home All Summer, the teacher asks the children on their last day at school about their plans for summer. Sixten says that he will go to Legoland, Sara says that she will go to Thailand. Then the narrator claims that he/she will go on a safari. Eventually the narrator's mother arranges a local "safari" at a lake nearby. Then Sara turns up, and it is obvious that the fancy plans did not become realized. These kind of responses to social expectations that one is unable to live up to can be regarded as a way of fitting in or, to apply Skeggs's concepts, as a call for respectability, by claiming to have what is expected according to middle-class norms. The pursuit for respectability becomes more urgent for those who are subordinated and regarded as other, and are therefore in need of proving themselves to be respectable. ${ }^{34}$ The child narrator suffering from socioeconomic exposure is subordinated both due to young age and to lack of economic means. However, he/she is aware of the economic conditions. The adult-child relation within the family is, in this respect, relatively equal. 35

The pursuit for respectability is put to the fore verbally and visually. On the spread depicting the evening before the child narrator is due to go on an excursion, the mother puts duct tape on the child's worn-out boots. On the left page, the child is holding the repaired boots, looking disappointed or at least thoughtful. The verbal text tells of her expectations of getting new boots with dots. In a thought bubble, there is a picture of an astronaut on the moon wearing the boots that, according to the narrator, look like space boots. The fantasy does not merely bring comfort but becomes ambivalent when in combination with the child's announced wish and worried face in the picture. ${ }^{36}$ Imagination and fantasy are not always sufficient to deal with disappointments, caused, as in this case, by lack of material means. In other words, the spread questions imagination and play as a comprehensive solution to material inequality.

The next spread pictures the excursion, where the children are having a barbeque. The verbal text tells of the educator's disdain for the child's repaired boots:

Now tell mum that it is time to buy new rubber boots, she says while handing them to me.

I say nothing. 37 
This silence, made explicit, indicates a deep sense of shame but also an awareness of the family's lack of money. Perhaps she is ashamed, as Nordenstam suggests, though the text does not say. ${ }^{38}$ The clash between the educator's supposedly caring utterance and the resulting silence make differences in class visible. The reaction can also be perceived as a quiet response to the experience of prescribed disrespectability. The narrator knows that their mum is incapable of doing what she is told, not because of carelessness but because of her lack of money. This is only one example of how this book focuses the lack of economic means, not a social exposure including lack of various sorts of capital.

The verbal text on this page also tells us that Sixten says that he is going to the cinema, while the narrator states that he/she also might do that. The visual presentation shows the narrator looking a bit anxious at one of the children, probably Sixten, who, on the contrary, looks excited. Two other children seem to engage in a conversation, while one of them is feeding sausage to some ants. The (preschool) teacher is pictured as a young woman wearing a ponytail and blue jeans. The supposed kind comment is unintentionally harming, while exposing a gap between different perspectives coming out of different economic premises. The visual presentation focuses on the children's interrelations, especially the bothered appearance of the narrator.

The next spread establishes a shift, since it not only exposes a lack of economic capital but also access to cultural capital. Mother and daughter are at the public library as a substitute for the cinema they cannot afford. The verbal text states that they borrow no fewer than twenty books, according to the picture including children's classics such as Trollvinter by Tove Jansson. While free of charge, fuel or bus tickets aside, a visit to the library presents a worthy alternative to cinema and helps enhance the cultural capital.

The spread depicting the library interior shows book covers, including iconic titles by Tove Jansson, Astrid Lindgren and Elsa Beskow as well as less known references. The observant reader might also notice the cover of a contemporary Swedish picturebook, Tilly som trodde att ... by Eva Staaf and Emma Adbåge published in 2014. This book is placed open on the floor in the protagonist's room on the last spread, emphasizing the literary intertextuality. Just like The Week Before Child Benefit Payment, this title depicts various living conditions in contemporary Sweden. Of course, this connection is not obvious for every reader, whether child or adult. It calls for a certain 
amount of cultural capital from the reader as well. Hence, this subtle reference forms a more restricted address, related to class in terms of cultural capital. The intertextual references by visual depictions of other contemporary children's literature are not only there to create an effect of reality, but also indicate a way of reading this picturebook and further elaborate the manifestation of the family's socio-economic status.

In Johansson and Ekman's book, the consumer society is made visible on every single page. The pictures contain visual references to 'cheap' brands like the laundry detergent in the bathroom indicating the logotype of Eldorado. There are also popular cultural elements such as My Little Pony, Ninja Turtles and the Swedish cartoon Bamse. No labels are spelled out, but readers can recognize various brands based on the shapes and colours of their logos: Kikkoman, 7-Eleven, Ica supermarket, and so on. This is in line with a wider trend of increasing presence of brands and logos in contemporary Swedish children's picturebooks, while in this particular case, the commercial packaging does not only, or even primarily, serve the function of representing everyday life in general. ${ }^{39}$ It can also emphasize economic aspects while putting class and class differences to the fore. They may offer readers possibilities of material recognition, at least for those familiar with the specific logotypes.

The interior is pictured in detail, with breadcrumbs and coupons on the table, and toys on the floor. The impression is messy, a realistic depiction of everyday family life but also a manifestation of class, albeit an ambiguous one. In Wistinsen's reading, this aspect of the depiction confirms the stereotyped views of the poor. 40 When analysing the portrayal from a class perspective instead of from a point of view of poverty, alternative interpretations of the crumbles become possible. As dirt can be associated with gender and class, the strive for tidiness can be regarded as, recalling Skeggs's concept, a strive for respectability, making the urge to present a clean and tidy home crucial for the working class and unprivileged minorities. In contrast, a more relaxed attitude to dirt and crumbles may indicate access to certain means.

\section{FRIENDSHIP IN LATE CAPITALISM}

A more thorough social-realistic approach is to be found in Uje Brandelius and Clara Dackenberg's At Harald Henriksson's Home. This multi-layered picturebook displays conflicts in a contemporary class-ridden society, while telling about two young 
friends on a play date. Dackenberg has illustrated several children books, and this title is the author's literary debut. Brandelius is a musician and former journalist. In 2009-2016, he worked as press secretary for the Left party [Vänsterpartiet].

A young protagonist and first-person narrator of the book is depicted with mostly feminine attributes and, hence, will be referred to as a girl even though the gender is not stated. She lives with her mother in a socially exposed suburbia with highrise estates visible from the window. Their flat is sparsely though colourfully furnished, with few toys or decorations. The book depicts the child and her mother travelling by bus, subway, and another bus, and they eventually end up in a well-off area on the opposite side of the city; later, it shows them going back again.

On their way to the Henrikssons, the family passes a toy store. In the display window, there is a Transformer toy that the narrator claims to want more than anything in the whole world. The text goes: "But I know that it costs a lot of money. So, I do not even badger." 41 Just like the competent child in The Week Before Child Benefit Payment, this narrator is well aware of her economic situation and she co-operates with her mother. As Nordenstam states in her analysis, children tend to be loyal to their parents no matter what. 42 Nevertheless, the narrator seems to lack the knowledge which the reader gathers via the visual presentation: that the children's friendship is steeped in economic relations as the mother is hired to clean Harald's house.

The mother and the child eventually reach Henrikssons' house, a huge villa. From now on, the pictures inform the reader that the mother has come to clean the house, while her child plays with the son, Harald, who lives there with his mother. The text indicates that this happens on a regular basis. It is notable that the mother of the protagonist uses paper plates for her packed sandwiches not to soil the kitchen table of her employer. This is not mentioned in the text but exemplifies how the visual presentation adds a class perspective to the verbal presentation that focuses on the child perspective and the friendship motive, even though the text itself is not as innocent or ideologically neutral as it might first seem.

In comparison to The Week Before Child Benefit Payment, the pictures in At Harald Henriksson's Home are less detailed. There are no signs of dirt in either of the homes depicted. However, dirt, or rather the ambition of getting rid of dirt, is fundamental to the story. It is by performing cleaning that the narrator's mother gets her income and is the basic reason why the narrator and her friend have met. 


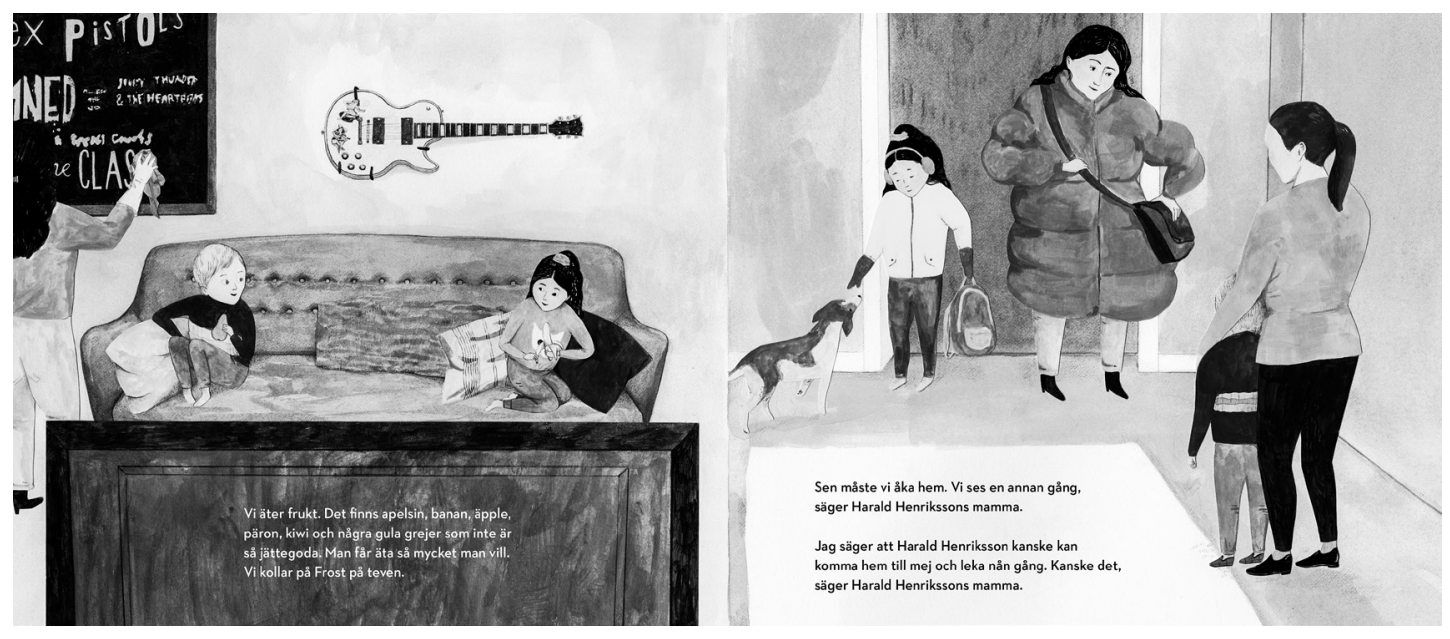

Fig. 2

Distances in At Harald Henriksson's Home. The hired cleaner erases the word 'class' from a punk poster in the fancy villa, while her child watches TV with the employer's son. 
Issues of class clearly intersect not only with structures of gender but also with ethnic background. The young narrator is visually defined as female, wearing pink earmuffs and a pink jumper with a cat on it. Both she and her mother have long dark hair, in contrast to the blonde short-haired boy Harald. These visual contrasts reflect the fact that most domestic cleaners are not born in Sweden. Class and national background intersect with power relations. One could interpret the protagonist's family as illegal immigrants, though that is not clearly stated.

The narrator's home is depicted as sparsely furnished, with few toys in evidence. There are no visible objects signalling the mother's cultural or social capital: she appears isolated, with no other interests except work and parenting her child. Nonetheless, the urge to own such a treasure as a Transformer becomes irresistible to her as she finds a similar toy hidden away at Harald Henriksson's place. The (adult) reader might notice the framed art posters in the spread, referencing leftist culture in the 1960s and 1970s. Former symbols of political protest have lost their cultural meanings, functioning in this context as identity markers that express a certain level of cultural capital. These decorations add an ironic dimension and display contemporary depoliticization; an idea that the book as a whole undermines. (Fig. 2)

On spread number eight, a picture shows the two friends sitting on the fringe of a sofa in front of a huge TV. ${ }^{43}$ In the background, the narrator's mother can be seen cleaning a framed poster that shows the punk band Sex Pistols. She wipes precisely on the word "class," literally and symbolically erasing the word from the supposed progressive identity of the adults paying to have their house cleaned.

Whether the work is undeclared is not explicitly stated but implicitly suggested. This brings to the fore the general conflict characterizing this book, since the mother's domestic work is not commented on at all, neither on this spread nor in the book in general. ${ }^{44}$ Further, the distinction between verbal and the visual text, that is presupposed by the concept of iconotext, is blurred since significant letters within the picture, rather than part of the typically separate text, are being wiped out. In this respect, aesthetic and political radicalness interplay.

The verbal text describes the villa from the child narrator's perspective. It is claimed to be "perfect because there are 'several million rooms to hide in'." 45 On the spread referred to above, the two children, living in different geographical and socio-economic margins of the town, are once again separated though they are in the same house. This is stressed visually. 
Play serves important functions in the manifestation of class and power relations. As Harald wants to play on his computer, the narrator prefers to play with his dog, claiming not to be very good at computer games. Though not made explicit, the depiction indicates that this is done in order not to reveal her lack of experience of such expensive activities. The basis of her lack in gaming skills is not declared but her warding off to avoid potential shaming is significant and is reminiscent of the strategies presented in Johansson's books.

Regarding the children's play, the carnivalesque subversion of power relations as they play master and servant is notable. The picture shows Harald kissing the narrator's feet, while the text adds that she makes him fetch things for her. ${ }^{46}$ What Skeggs states figuratively becomes literal in the depiction of the children transforming power relations in their play: "[I]t is only those who are wealthy who can play being poor." 47

As the next spread depicts the narrator and her mother having sandwiches in the kitchen while Harald Henriksson eats pasta in the dining room, the factual class differences are emphasized. As Skeggs puts it, "the most fundamental marker of class was that of exclusion". ${ }^{48}$ The differences of class are further stressed by the picture of the schedule on the fridge, declaring an extremely busy agenda that includes aikido, trombone, scouting, tennis, football, choir, and theater, revealing both economic and cultural capital. This means access to spaces that are without reach for the protagonist. Yet, the subtle exaggeration in the number of activities, can be regarded as an expression of subversive humor or an ironic, bitter-sweet characteristic echoing the illustration.

Back home, the worn-out mother is pictured lying on the sofa with a remote control in her hand. The spread resembles the one in The Week Before Child Benefit Payment, where the mother lies on a sofa, bored and tired of her lack of money. In a much sparser room, the narrator of At Harald Henriksson's Home plays Lego on the floor. The mother looks exhausted. The verbal text says that the child plans to return the transformer she has stolen from her friend, and telling her mum of the theft. Her facial expression indicates that she is ashamed, but her mum declares that she is not angry. Nonetheless, she does not let her child keep the toy. In other words, the economic transformation is only temporary, depicted as illegitimate, yet understandable. This could be regarded as an indication that the theft is viewed as somewhat legitimate.49 Nevertheless, this small transformation of means is temporary. As the book ends, the child's wish that Harald one day will come 
and visit her indicates, at least for an adult reader, of her childish lack of comprehension of the economic basis of their friendship. There is no transformation of power, no child becoming mighty as in Beauvais's reasoning. 50

The visual presentation of the mother's restricted body language and lowered gaze expresses incarnated subordination. The final spread, however, emphasizes the close mother-child relationship, showing them looking at each other in the light of the bed lamp. The mother's face is turned towards her child, whose wide-open eyes are in focus. The Transformer toy is still in their apartment but there are no signs of any transformation whatsoever.

\section{A BOURGEOIS NIGHTMARE}

The well-established Swedish picturebook creator Pija Lindenbaum has challenged various norms not by rejecting them, but rather, by playing with them. ${ }^{51}$ This goes for gender norms, but also, in some of her work, for class norms. In Siv Sleeps Astray, a playful title in comparison with the two more direct ones discussed above, the young narrator is about to spend the night at Cerisia's place. Siv has long blond hair and a T-shirt similar to that of her new red-haired friend. In an interview, Lindenbaum stated the T-shirt to be a cheaper version of that of her friend's. ${ }^{52}$ Else, I would argue that one could interpret Siv's version as basic, less feminine T-shirt, in comparison to her friend's designerlooking one, with puff sleeves. The friend has a symbolic name alluding to the colour pink that dominates the cover of the book and the visual presentation of Cerisia's home. The names stress the protagonist's ambiguous perception of her friend as exotic or fantastic. Cerisia lives in a huge state apartment with her mum, dad, a great-grandmother, a dog, and two guinea pigs-possibly transformed into two wild animals, the badgers named brawlers ["bråkstakarna"] that show up at night.

Siv is both fascinated and scared by this place that is so different from her own. Details of Siv's own home and family are very sparse, limited to visual and verbal depictions of her emotional reactions. For instance, she admires the fancy table setting at her friend's place. In general, this book deviates from the other examples where the realistic narrative mode merges with fantastic and grotesque features, especially in the play with proportions and perspectives. Scholarly writings on Siv Sleeps Astray have payed attention to its expressive multimodality. The changing ways of relating perspectives and the contrasting colours 
in the pictures bear engendered associations to the depiction of the young protagonist's dreamlike experiences in Alice in the Wonderland. ${ }^{53}$ Those familiar with Lindenbaum's popular books of Bridget can probably recognize the verbal and visual narrative structure in which the protagonist confronts her fears by means of fantasy and play when meeting with various creatures. 54

The first spread depicts the arrival of Siv and her dad at Cerisia's apartment. The father wears what looks like a bomber jacket and has his long grey-brown hair in a ponytail. Cerisia's mother wears cerise clothing and bracelets. There are fresh flowers in a vase and the furnishings are in a Rococo style. The apartment looks huge in the picture, with nine doors in the hallway. On the first spread, one can discern a person using a vacuum cleaner; later it becomes clear by the clothing that it is Cerisia's dad. The illustrations of the upper-crust apartment in Lindenbaum's book also depict crumbs as well as dog hair and dirty dishes, although there are recurrent signs of cleaning going on. In a picture of the kitchen on spread four there is a bucket and a scrubber on the middle of the floor.

Warnqvist has suggested that the visual presence of dirt in this case might be regarded as either a way of normalizing what the protagonist would consider a foreign environment or a way of moralizing the lack of cleaning. ${ }^{55}$ I would like to propose a third way of interpreting the dirt and the cleaning tools, namely as indicators of a struggle between order and disorder, the civilized and the uncivilized, that is a recurring motive in Lindenbaum's picturebooks.

The first-person narrator focuses on the smell of whey cheese and perfume, but also registers the number of doors. The next spread shows a room with stylish furnishings, though these are more modern. On the table, there is a design magazine, a fruit bowl, and the great-grandmother's dentures. In the posh interior, a highbrow culture blurs with slightly grotesque elements. Another example of the latter is the bump on the dog's head, emphasized both verbally and visually. Through Siv, both the old woman and the pets are presented as strange and creepy. Other things in the apartment are perceived as odd but impressive. At the dinner table, there are fancy napkins and candles: "We only have that when it is a party. They probably think it is a party when I am here," Siv says, though her face indicates doubt, even subordination, when the gaze is lowered.56

Food is made significant in relation to class in all of my picturebook examples. In this case, the dinner consist of a dish 
including couscous, which is depicted as unknown from Siv's point of view but is exotically labelled as "arabic" by Cerisia, who is used to this kind of food which she also indirectly declares. This recalls Skeggs's reasoning: "The entitlement and access to the resources for making a self with value are central to how the middle-class is formed; they have access to others' culture as a resource in their own self-making. In the relationship of entitlement class is lived and experienced.”57

Cerisia is portrayed as frequently giving herself advantages in relation to Siv, for instance claiming the last bit of ice cream and the most comfortable bed. She justifies her privileges with arguments made in an adult manner, though the content of her arguments is not very convincing. As Warnqvist has noted, these claims are based on ownership. ${ }^{58}$ The dominant behavior is pronounced in the pictures, for instance on spread eight, where Cerisia's mother is depicted preparing a mattress on the floor for her daughter to sleep on. The guest is supposed to sleep well, the mother says. The image on the left shows Cerisia sitting at the end of her bed looking angry and with her arms crossed as if in protest. To the right, there is another picture showing Siv on the mattress, while her friend is lying in her royal-looking black bed, with an arched headboard. Siv lacks the social and cultural capital her friend makes use of in order to hold her back, not only to claim privileges but to legitimize and naturalize the inequality.

Just as in Lindenbaum's book series on Gittan, published in 2000-2013, realism merges with or transforms into a fantasy or a dream that reflect the feelings of the main character. 59 The transitions are usually marked by a change of colours, and in this case, even shapes and proportions change. When lying awake at night, Siv realizes that both her friend and the dog have left the room. Siv starts walking around the apartment searching for Cerisia. First, she bumps into the parents, dressed up in crinolines and party hats, eating a huge cake: "It looks like Cerisia's mother and father. But it is probably somebody else." 60 On this spread, the visual manifestations of the asymmetric power relations Siv experiences during her stay become exaggerated and grotesque, in a fantastic or dreamy vision featuring both age and class.(Fig. 3)

The wealth and even the gluttony associated with the friend transform into a horror vision of her two enlarged dressed-up parents overindulging on cake and sweets. Siv shuts the door and continues the search for her friend on her own, as the sight is too creepy to bare. These examples of places where realism merges with fantasy, evoke Reynolds's reasoning on how transformations 


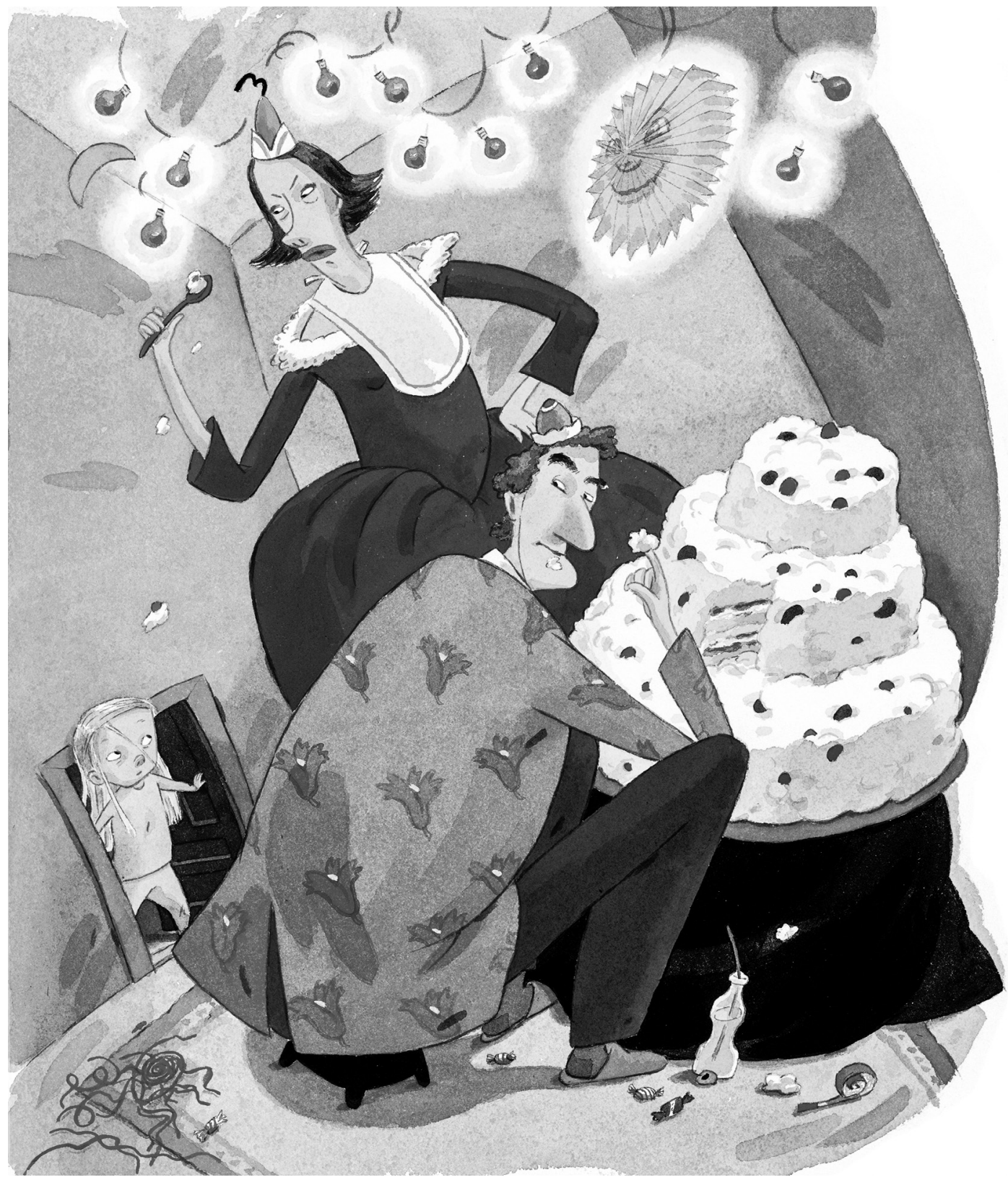

Fig. 3

A nightmare in pink? During the night, Cerisia's parents consume huge, overindulgent sweets in a dreamlike vision in Siv Sleeps Astray. 
within magic(al) realism "correspond closely to the conditions of childhood and adolescence, which are intrinsically about change, metamorphosis, and growth of body and mind."61 Further, Reynolds claims that magic(al) realism can also be a way of working towards social change. In this case, it ends with a change of the protagonist's views and feelings, by strengthening her sense of belonging in a familiar environment-at home with her dad.

Eventually, after having bumped into the badgers, Siv finds her friend on the toilet (which is not mentioned in the text). Hence, her sudden disappearance acquires a reasonable explanation, even though the relation between reality and dream stays blurred, and the badgers appear in the same picture. They are also mentioned in the verbal text: "They probably do not want to be bossed," Siv says, and Cerisia agrees. ${ }^{62}$ This conforms the reading of the brawlers as transformed guinea pigs. ${ }^{63}$ It also recalls the fantastic beings in Maurice Sendak's classic picturebook Where the Wild Things Are (1963), in which the young protagonist travels by night to a land of symbolic wild magical creatures. In this book, fantasy is also associated with resistance, power, and adultchild relations, though not in reference to class. The intertextual connections between Lindenbaum's picturebooks, especially Siv Sleeps Astray and Bridget and the Grey Wolves (2000), and Sendak's classic, affirm Warnqvist's notion of fantasy as a means of resistance. However, I would like to add, when considering how the verbal text makes Cerisia co-operate in imagining/seeing the brawlers, or transformed guinea pigs, fantasy is not manifested as an individual act of resistance. Such a view would imply an intention, whereas I would rather stress the function of fantasy as one with political implications linked to the protagonist's initially ambivalent relation to her friend's fancy environment and shameless, privileged behaviour.

The presentation of the two children's unequal position reflects the different living conditions, their class clash. On the final spread, Siv is on her way home with her dad, concluding: "Now I have slept over. It was not that much fun." 64 The homesweet-home location is re-established. The sense of belonging intertwines with a certain class position that differs from Cerisia's, in comparison, blue-rinse living conditions. In contrast to the working-class females in Skeggs's study, Siv does not disassociate from her own class but from her friend's alien upperclass position. 


\section{FINAL REMARKS}

By analysing these three picturebooks, I have tried to shed light on the means by which social class is manifested visually and verbally. All of them use the multimodality of the picturebook in various ways. The more explicit approach to class in some picturebooks during the 2000s and the 2010s coincides with a norm-critical discourse including a strong emphasis on diversity and children's experiences represented in children's literature. In this, the contemporary Swedish radical picturebook deviates from the political picturebook of the 1970s, which used literary and multimodal means to present an analysis of the economic system and to depict and/or promote a radical change on a collective level. As I have tried to show, the thematic of class in more recent radical picturebooks is presented as a complex, multimodal doing of diversity than a doing of revolution. However, the books offer a literary and visual analysis of class and inequality, though a call for transformation is not made explicit.

In both The Week Before Child Benefit Payment and At Harald Henriksson's Home, the verbal text primarily displays a child's perspective, focusing on the experiences of the young narrator, while the pictures add further social context. That goes to the extreme in the last mentioned title, in which the class thematic is to be find in the visual presentation. There is even a class analysis brought to the fore by the iconotextual counterpoint, displaying opposing perspectives of the relations and the plot. In At Harald Henriksson's Home not only consumption but also the means of production are highlighted, which brings about an economic analysis of the conflict depicted. The iconotextual basic distinction between pictures and words is sometimes blurred as verbal elements are integrated in the pictures. While not unique for these books, my point is that this aesthetic approach is linked with political radicalness, This is particularly made apparent in At Harald Henriksson's Home, on the spread where the word 'class' is wiped out. In this book, the visual presentation is crucial for the reader to grasp the fundamentally unequal economic premises of the thematic of friendship displayed by the verbal text.

In The Week Before Child Benefit Payment, the detailed pictures expands the realistic verbal text and the dialogue by various kinds of intertexts. The pictures make visual the family's lack of economic capital, as well as a certain access to a cultural capital. Such resources are not to be found in the more heavyhearted, sparse depiction of the narrator and her mother in $A t$ Harald Henriksson's Home. 
Siv Sleeps Astray merges social realism with magic realism. It gives a more fantastic presentation of class differences or even class collision by depicting Siv's ambiguous, dreamlike experiences in her friend's fancy home. This is already indicated by the playful title of this book. Just like in the other examples, class is made manifest by visual attributes, and sometimes verbal comments, regarding food, clothing, dirt, and interior design. Class relations are thus demonstrated through the focus on the field of consumption. But they are also put to the fore through the depiction of habitus; the privileged friend's self-evident reasoning and the quietness of the narrator.

The narrative uses of play and fantasy might display comfort and even a temporary transformation by exaggerating (as in the sleep-over experience in Siv Sleeps Astray), or changing power relations (as in the children's play in At Harald Henriksson's Home), or by bringing the characters tools to handle a lack of economic means (The Week Before Child Benefit Payment). This exploiting of literary and visual strategies is connected with political aspects on different levels. In the final pages of the three picturebooks, the class inequalities that have been presented persist. In the three books examined, the endings depict the child protagonist and the single parent happily united, no matter what forms of class differences and inequalities they have experienced due to their inferior social position. The narrators/protagonists are all depicted as confident, though the relations of power are kept intact. There is no radical transformation made explicit verbally or visually. Whether some kind of change nevertheless is promoted by these manifestations of class and inequalities, is more difficult to tell. 
1 Svenska barnboksinstitutet, "Bokprovning på Svenska barnboksinstitutet: En dokumentation Årgång 2018: 27 mars-16 maj 2019", https://www.barnboksinstitutet.se/ wp-content/uploads/2019/03/Dokumentation-2019. pdf [2019-10-04], 5, my translation of the original: "huvudsakligen på att uppmärksamma orättvisor, synliggöra sociala och ekonomiska skillnader och att engagera barn i protesthandlingar."

2 Lena Kåreland, Inga gåbortsföremål. Lekfull litteratur och vidgad kultur - debatt i 1960- och 70-talens Sverige (Göteborg, Makadam, 2009); Olle Widhe, "Counterindoctrinations: Radical Childcare Books, Children's Literature and Children's Rights in Sweden around '68", Strenæ [En ligne], 13 | 2018, mis en ligne le 15 mai 2018, consulté le 10 septembre 2020. URL: http:// journals.openedition.org/strenae/1907.

3 Kristina Hermansson and Anna Nordenstam, "A New Niche in Children's Literature. Norm-Crit Picturebooks in Sweden" in Lir-journal 9:17, issue: "Performing the Child. Power and Politics in Children's Literature and Culture" (2017): 97-120.

4 Pija Lindenbaum, Siv sover vilse (Stockholm: Rabén \& Sjögren, 2009).

5 Elin Johansson and Ellen Ekman, Veckan före barnbidraget (Stockholm: Rabén \& Sjögren, 2016).

6 Uje Brandelius and Clara Dackenberg, Hemma hos Harald Henriksson (Stockholm: Lilla Piratförlaget, 2018).

7 Boel Westin, "Svenska bilderböcker 1954-1980", in Läs mig sluka mig: en bok om barnböcker, ed. Kristin Hallberg (Stockholm: Natur och kultur, 1988); Lena Kåreland, Inga gåbortsföremål. Lekfull litteratur och vidgad kultur - debatt i 1960- och 70-talens Sverige (Göteborg: Makadam, 2009); Widhe, "Counterindoctrinations: Radical childcare books, children's literature and children's rights in Sweden around '68," in Barnlitteraturens värden och värderingar, eds. Sara Kärrholm and Paul Tenngart (Lund: Studentlitteratur, 2012).

8 Rolf Knutsson and Mats Andersson, Josefine, 5, Zimbabwe, Afrika (Stockholm: Rabén \& Sjögren, 1971).

9 Lotta Silfverhielm, Spikarligan (Stockholm: Rabén \& Sjögren, 1971).

10 Annika Elmqvist, Sprätten satt på toaletten (Stockholm: Rabén \& Sjögren, 1970).

11 Widhe, "Counter-indoctrinations: Radical childcare books, children's literature and children's rights in Sweden around '68."

12 Olle Widhe, Bokprovning på Svenska barnboksinstitutet En dokumentation. Årgång 2018: 27 mars-16 maj 2019, https://www.barnboksinstitutet.se/wp-content/ uploads/2019/03/Dokumentation-2019.pdf.

13 Lydia Wistisen, “'Har du inga gummistövlar?': fattigdom i 2010-talets svenska bilderbok" in Barnboken 42 (2019), http://dx.doi.org/10.14811/clr.v42i0.405.

14 Anna Nordenstam, "Tre berättelser om Sverige: fattigdom och klass i Veckan före barnbidraget, lggy 4-ever och Wage slaves," in Konstellationer: festskrift till Anna Williams, eds. Borg et al. (Möklinta: Gidlunds, 2017), 311, my translation of the original: "Det här är svensk vardagsrealism."
15 Pija Lindenbaum, Else-Marie and her seven little daddies, trans. Gabrielle Chardonet (New York: Holt, 1991).

16 Pija Lindenbaum, Else-Marie och småpapporna (Stockholm: Bonniers, 1990)

17 Maria Österlund, "Att formge en flicka: flickskapets transformationer hos Pija Lindenbaum och Stina Wirsén," in Flicktion: perspektiv på flickan i fiktionen, eds. Söderberg et al. (Malmö: Universus Academic Press, 2013). Regarding the concept "gurlesque", see Lara Glenum and Arielle Greenberg, eds., Gurlesque: the new grrly, grotesque, burlesque poetics (Saturnalia Books, Philadelphia, PA, 2010), in particular Arielle Greenberg, "Some notes on the origin of the (term) grotesque," in Gurlesque, The new grrly, Grotesque, Burlesque Poetics.

18 Maria Österlund, "Kavat men känslosam: den komplexa bilderboksflickan i Pija Lindenbaums Gittan-trilogi," in Barnlitteraturanalyser, eds. Maria Andersson and Elina Druker (Lund: Studentlitteratur, 2008).

19 Österlund, "Att formge en flicka: flickskapets transformationer hos Pija Lindenbaum och Stina Wirsén."

20 Maria Österlund, "Mångfaldiga former. Aktuell barn- och ungdomslitteratur i ett könsperspektiv", The history of Nordic women's literature, 16-10-02, https://nordicwomensliterature.net/se/2016/10/12/ maangfaldiga-former-aktuell-nordisk-barn-ochungdomslitteratur-i-ett-konsperspektiv/.

21 Åsa Warnqvist, "Att vägra normen och att omsluta den: Pija Lindenbaum som normkritiker," in Barnlitteraturens värden och värderingar.

22 Kimberley Reynolds, Radical Children's Literature: Future Visions and Aesthetic Transformations in Juvenile Fiction (New York: Palgrave Macmillan, 2007), 1.

23 Cleméntine Beauvais, The mighty child: time and power in children's literature (Amsterdam: John Benjamins Publishing Company, 2015).

24 Julia Mickenberg and Philip Nel, "Radical Children's Literature Now," Children's Literature Association Quarterly 36: 4 (2011).

25 Kristin Hallberg, "Litteraturvetenskapen och bilderboksforskningen," Tidskrift för litteraturvetenskap 3-4 (1982).

26 Pierre Bourdieu, Distinction: a social critique of the judgement of taste (Cambridge, Mass.: Harvard University Press, 1984).

27 Beverly Skeggs, Formations of Class and Gender: Becoming Respectable (London: Sage, 1997), 3.

28 Skeggs, Formations of Class and Gender: Becoming Respectable, 3.

29 Elin Johansson and Ellen Ekman, Hemma hela sommaren (Stockholm: Rabén \& Sjögren , 2018).

30 Maria Österlund, “'Se så söt du blir i den här.' Maktkamp, generation och genus i Carin och Stina Wirséns bilderböcker," Barnboken, 31(2), 2011, https://doi. org/10.14811/clr.v31i2.61, 5.

31 Nordenstam, "Tre berättelser om Sverige. Fattigdom och klass i Veckan före barnbidraget, Iggy 4-ever och Wage Slaves." 
32 Nordenstam, "Tre berättelser om Sverige. Fattigdom och klass i Veckan före barnbidraget, Iggy 4-ever och Wage Slaves."

33 Maria Nikolajeva and Carole Scott, How Picturebooks Work (New York: Garland, 2001), 238.

34 Skeggs, Formations of class and gender: becoming respectable.

35 Johansson and Ekman, Veckan före barnbidraget, spread 6, my translation of the original: "Då kommer jag ihåg vilken vecka det är, veckan innan barnbidraget."

36 Johansson and Ekman. Veckan före barnbidraget, spread 5.

37 Johansson and Ekman, Veckan före barnbidraget, spread 6, my translation of the original: "Säg nu åt mamma att det är dags att köpa nya, säger hon när hon räcker mig dem. / Jag säger ingenting."

38 Nordenstam, "Tre berättelser om Sverige: fattigdom och klass i Veckan före barnbidraget, Iggy 4-ever och Wage slaves."

39 Martin Hellström, Förpackningens förvandlingar: konsumtion och karneval i barnboken, diss. (Linköping: Linköpings universitet, 2011).

40 Wistisen, "Har du inga gummistövlar? Fattigdom $\mathrm{i}$ 2010-talets svenska bilderbok," 9.

41 Brandelius, Hemma hos Harald Henriksson. My translation of the original: "Men jag vet att den kostar jättemycket pengar. Så jag tjatar inte ens," spread 2.

42 Nordenstam, "Tre berättelser om Sverige. Fattigdom och klass i Veckan före barnbidraget, Iggy 4-ever och Wage Slaves."

43 Brandelius, Hemma hos Harald Henrikson, spread 8. My translation of the original: "Man får äta så mycket man vill."

44 Nikolajeva and Scott, How Picturebooks work (New York: Routledge, 2006).

45 Brandelius, Hemma hos Harald Henriksson, spread 4. My translation of the original: "perfekt för det finns flera miljoner rum att gömma sig i."

46 Brandelius, Hemma hos Harald Henriksson, spread 5.

47 Skeggs, Formations of class and gender: becoming respectable, 92.

48 Skeggs, Formations of class and gender: becoming respectable, 162.

49 Wistisen, "Har du inga gummistövlar? Fattigdom i 2010-talets svenska bilderbok," 11.

50 Cleméntine Beauvais, The mighty child: time and power in children's literature (Amsterdam: John Benjamins Publishing Company, 2015).

51 Åsa Warnqvist, "Att vägra normen och att omsluta den: Pija Lindenbaum som normkritiker," 181-203.

52 Stefan Eklund, "Tecknade bilder av klass," Svenska Dagbladet, 2009-10-01, related by Åsa Warnqvist, "Att vägra normen och att omsluta den: Pija Lindenbaum som normkritiker," Barnlitteraturens värden och värderingar, 199, and in Österlund, "Att formge en flicka: flickskapets transformationer hos Pija Lindenbaum och Stina Wirsén," 40.

53 Åsa Arping, "Att våga eller inte: små och stora kriser i Pija Lindenbaums bilderboksvärld," Arche (Göteborg), 44/45 (2013).
54 See for instance Warnqvist, "Att vägra normen och att omsluta den: Pija Lindenbaum som normkritiker," Arping, "Att våga eller inte: små och stora kriser i Pija Lindenbaums bilderboksvärld."

55 Warnqvist, "Att vägra normen och att omsluta den: Pija Lindenbaum som normkritiker."

56 Lindenbaum, Siv sover vilse, spread 6. My translation of the original: "Det har vi bara när det är fest. Dom tycker nog det är fest när vi är här."

57 Skeggs, Formations of class and gender: becoming respectable, 183.

58 Warnqvist, "Att vägra normen och att omsluta den: Pija Lindenbaum som normkritiker."

59 Österlund, "Kavat men känslosam: den komplexa bilderboksflickan i Pija Lindenbaums Gittan-trilogi."

60 Lindenbaum, Siv sover vilse, spread 11. My translation of the original: "Det ser ut som Cersias mamma och pappa. Fast det är nog några andra."

61 Reynolds, Radical children's literature: future visions and aesthetic transformations in juvenile fiction.

62 Lindenbaum, Siv sover vilse, spread 14. My translation of the original: "Dom vill nog inte bli bestämda över."

63 Warnqvist, "Att vägra normen och att omsluta den: Pija Lindenbaum som normkritiker."

64 Lindenbaum, Siv sover vilse, spread 16. My translation of the original: "Nu har jag sovit över. Det var inte så jättekul." 